World Lumen Congress 2021 | May 26-30, 2021 |

lasi, Romania

\title{
Information and Communication - The Limits of Media Discourse. Case Study - Romanian School in the News
}

\author{
Xenia NEGREA
}

https://doi.org/10.18662/wlc2021/49

How to cite: Negrea, X. (2021). Information and Communication - The Limits of Media Discourse. Case Study - Romanian School in the News. In A. Sandu (vol. ed.), Lumen Proceedings: Vol. 17 World Lumen Congress 2021 (pp. 492-497). Iasi, Romania: LUMEN Publishing House. https://doi.org/10.18662/wlc2021/49 


\title{
Information and Communication - The Limits of Media Discourse. Case Study - Romanian School in the News
}

\author{
Xenia NEGREA ${ }^{1}$
}

Abstract

In this study we propose an analysis of the media discourse on education. This paper is based on questions such as: in what manner is the media an echo for the public policy authors, for the dominant ideology, and what are the stories featuring the school topic. Using the content analysis, we aimed to find the narrative frames, and a map of the most cited journalistic sources. We found that the media is a very important source for public agenda. In fact, the media is one of the most powerful public and social policy agents. Our analysis covers the journalistic discourse in Romania for a period of one year, from the moment of declaring the state of emergency. One of the bypotheses was that the type of journalistic discourse under analysis is specific to crisis communication. Regarding the corpus of texts, we selected a publication where there are published only features on education, edupedu.ro, a quality publication with stories from different fields, including education, libertatea.ro, and a soft publication, kanald.ro. The texts were analysed from a multidisciplinary perspective, in order to define and describe a narrative pattern. One of our main findings is this fear of contaminating the quality press with false information. And, as a consequence, we have found a journalistic conformism and a lake of creativity and new approaches, respectively assuming a role of facilitating the information, of carrier, rather than of a watchdog.

Keywords: education; journalism; public policy; conflict; entertainment.

\section{Introduction}

Journalism is a type of communication that works constantly under pressure. The "urgency of communication" characterizes, in fact, the professional journalistic rhythm. Journalistic communication is also under the sign of novelty and under the market laws. Between these extremes, the press must fulfil a series of socio-discursive functions: the function of information, interpretation, connection, education, entertainment.

1 University of Craiova, $\mathrm{PhD}$, Journalism Specialization, Craiova, Romania, xenia.negrea@gmail.com 
Journalism responds to the laws of the market to what is called news value; there are the main pragmatic items that transform an event into journalistic material. Those items bring together characteristics of journalistic content relating to frequency, routine, affected and involved people, their relevance from different perspectives, the emotional charge of features, etc. The news criteria filter supports editorial decisions and directs journalistic discourse to a certain number and type of receivers.

The press also assumes a certain role, depending on the relationship with the Establishment. It is a relationship that the journalist establishes, recognizes and accepts, and it should be declared. Modern theories explain the social roles of the press starting from the way the journalists view themselves in relation to the Establishment, and weather the Establishment itself is weak or strong.

The question of this study is (Q) How does the journalistic perception of one's mission change under pressure, during a crisis, similar to the one we are going through?

We use the term "crisis" in the sense of a time gap between routine procedures and new problems (Roberts \& Dzieglielewski, 1995). This gap, this asynchrony between new procedures and problems generates creative solutions (Taylor et al., 2007). Thus, we wanted to see how journalists understand to fulfil their role in the context of the new crisis.

We arrive at the second hypothesis of our study. From the first moments of the declaring the state of emergency, the quality and soft journalism assumed a monitoring role, in form, and a facilitating role, of informational posting, in fact (Clifford et al., 2009).

In the public space, the topics related to the health issue were approached together with the educational topics. Online school and digital training or teachers' illiteracy are the main topics that have fed the journalistic discourse about the Romanian educational system. Until now, topics about the educational aspects were in the area of scapegoating narratives (Fisher, 1989). This type of narrative is built on the rhetoric of guilt, of accusation, and the main subject of this construction was the teacher. We also researched if and how much of this rhetoric was preserved.

\section{Journalistic educational topics during the medical crisis}

For this analysis we chose three publications. A publication intended exclusively for educational purposes (edupedu.ro), a publication that assumes the mission of quality journalism (libertatea.ro) and a television site (kanal D.ro). We chose these publications primarily because they were not 
related to any political partisanship. The first is dedicated exclusively to education and research issues; the second has undergone a discreet but vigorous rebranding process, from tabloid journalism to quality journalism, through investigations and reports that have been cited by many national media institutions. The last one has employers from outside Romania, is a general channel, with programs in the area of entertainment, and the news journals are structured in the area of soft and spot news (Metzler, 1986).

We analyzed a total of 3,358 texts (news, stories, reports), from the moment of the state of emergency (March 16, 2020) until April 10, 2021. We followed the thematic field and the sources used by journalists.

Regarding the selection of topics, the journalists from edupedu.ro gave space and importance to the following topics: the degree of infection in schools, testing in schools, financing of studies, changing the structure of the school year, together with the exams, and educational tests. Of the 2960 materials analyzed, $48 \%$ had as source and subject the decision-makers. By decision-makers we mean both members of the government (prime minister, minister, secretary of state), the presidency, but also the coordinators of medical actions (the strategic communication group, the coordinator of the vaccination campaign). The journalists retrieve their public interventions, in the form of press conferences, briefings, announcements, press releases, and statements. The motivation of these actions was the transmission of official information to the public. $4 \%$ of the materials were about pupils and students. Most of the materials also came as routine events, statements, press releases of student organizations, official letters. Edupedu.ro also published topics related to the academic context: 3\%. These materials were about plagiarism, the scandal of online evaluations, university responses to the state of emergency, institutional statements. Parents and teachers cover one percentage of the materials dedicated to the education system. The parents are present mostly through institutional communication, meaning through the press releases and statements made by several association leaders. The news about teachers refers to the protests and working conditions. $43 \%$ of the news focus on comparisons with foreign educational systems, the involvement of economic agents in education, usually through donations, COVID protection methods or materials that do not have a direct (or in the best of cases, a very weak one) connection with the analysed topic.

The newspaper libertatea.ro dedicates a full section to the school year 2020-2021, and there we can find all the news on this topic. All the materials published by Libertatea are written in the pandemic context. We analyzed 310 materials (news and reports). 39\% of these are based on the statements made by decision makers (Minister of Education, Prime Minister, 
President of Romania, government representatives in the territory). Parents are the source of $5 \%$ of the materials (which refer to the possibility of staying home to supervise children during online school, ways to protect against COVID). Students are the source of $6 \%$ of the materials, and the teachers are the source of $4 \%$ of these materials, including the positions of the various unions in the field. These materials published by Libertatea revolve around the structure of the school year (1), the vaccination survey, the need for specialization for online teaching; some of the risks the teachers are subject to, the opinions of some experts on how online school should be managed. $46 \%$ of the materials refer to the effects of COVID (announcements of school closures, number of infected people, etc.). Moreover, the journalists from libertatea.ro gave space and importance to the following topics: the school year structure, student testing, exams, return to school scenarios, vaccination of teachers, poor conditions of students, and lack of teacher training.

On the Kanal.D website, we identified 88 materials for the period in question. $92 \%$ of these are built on the logic of routine events, namely press conferences, press briefings, statements, decision-makers, regulations, official announcements. Other reports are part of the category of conflicts $(8 \%)$ and are about: the death of students and erotic scandals with teachers as protagonists. No parent is the main source of these materials. The topics cover the starting of the school, regulations and procedures, as well as the issue of offering small spring presents under the current conditions. There is only one text that explores the students' life and problems, and that is built starting from a statement of a public figure named Selly. We couldn't find these topics in the other two publications that we analysed. However, the attention of journalists is focused on creating suspense, emphasizing conflicts to get attention, arousing curiosity through sentences that underline the use of rhetorical interrogations.

\section{Findings}

The discourse refers to the rational world (Fisher, 1989). The journalists relied mainly on information taken from the statements made by decision-makers, whose identity has now overlapped with that of experts in the health field. The texts are therefore logical and argumentative.

This is a first result of our research: in addition to the urgency of assimilating a rather specialized field, medical journalism, the journalists themselves, as well as their sources, had to communicate remotely, respecting a series of protocols imposed by the health crisis. Journalists are, 
therefore, on two fronts: rapid adjustment to a specialized field, the acquisition of new professional skills and the rapid assimilation of physical protection procedures.

The press is facing a sharp increase of the public interest and that brings a rethinking of journalistic agenda. The press was no longer reluctant to cover a topic, but the common topic of press references was misinformation and the phenomenon of fake news.

The topic "infernal spiral" (Monnier, Thuillier, 2009) has accumulated in this new crisis terms such as: conspiracy, misinformation, fake-news. This is the context, the ambiance that affects both, the issuer and the receiver. And journalists have started a genuine fight to protect their credibility.

\section{Conclusions}

Our analysis has shown that this conformity, this status of communication channel is a characteristic of the mediated discourse in the analyzed period. When we do not talk about politically ideologized discourses, we are focused on an extremely prudent journalism, which does not abandon the Establishment's agenda. The effects of minimal dramatization, the logic of serialization (Lits, 2010), and the development of rhetoric surrounding the health crisis (structured on the idea of statistics, heroes, regression, fed by insistent moral connotations) are minimal. So far, in the medical crisis, the press has had to deal with a lack of public confidence on the one hand, and, on the other hand, with a professional discourse undermined by fake journalism structures. These structures do not have an interest in informing the audience and create a coherent informational link between the Establishment and the public, with a view to jamming and disturbing this connection.

\section{References}

Clifford, G. C., Theodore, L. G., McQuail, D., Nordenstreng, K., \& White, R. A. (2009). Normative theories of the media. Journalism in democratic societies. University of Illinois Press.

Fisher, W. R. (1989). Human communication as narration: Toward a philosophy of reason, value, and action. Philosophy and Rhetoric, 22(1), 71-74.

https://philpapers.org/rec/FISHCA

Lits, M. (2010). Pourquoi les medias n'ont-ils rien vu venir? [Why didn't the media see it coming?]. In V. Dujardin, Y. de Cordt, R. Costa \& V. de Moriamé (Eds.), La crise économique et financière de 2008-2009. L'entrée dans le 21e siècle? 
[The 2008-2009 economic and financial crisis. Entering the 21st century?] (pp. 81-85). Peter Lang.

Metzler, K. (1986). Newsgathering. Prentice Hall.

Monnier, F., \& Thuillier, G. (2009). Crise. Niveau de vie. Conflits [Crisis. Quality of life. Conflicts]. Economica.

Roberts, A., \& Dzieglielewski, S. (1995). Foundation skills and applications of crisis intervention and cognitive therapy. In A. Roberts (Ed.), Crisis intervention and time-limited cognitive treatment. Sage Publications.

Taylor, K., Durant, R., \& Boje, D. (2007). Telling the story, hearing the story: Narrative co-construction and crisis research. American Communication Journal, 9(1). http://ac-journal.org/journal/2007/Spring/articles/coconstruction.html

Vladutescu, S. (2013). The communication membranes. European Scientific Journal, 9(32). https://doi.org/10.19044/esj.2013.v9n32p\%25p 